Alicante Journal of English Studies 26 (2013): 175-191

\title{
The Mystory: The Garage D'Or of Ereignis
}

\author{
Barry Jason Mauer \\ University of Central Florida \\ bmauer@ucf.edu
}

\begin{abstract}
The performance of identity involves impression management, social skills, and self-reflexivity. To perform identity in media environments involves writing our identities into being. Media environments have facilitated a new kind of selfhood - brand - in which we model our identities on celebrities. However, because brand identity has no ethical grounding, it raises legitimate concerns. To incorporate ethics, I perform my identity through mystory, Gregory Ulmer's genre of reflexive writing. By composing a mystory, I consult with an avatar - which in Hindu tradition was a god descended into earthly form - that reveals my ethical condition and a pathway through it. This consultation functions as pharmakon (Derrida, 1995), revealing truths to me which both wound and heal. I use mystory to address a personal question, "How do I lead an ethical life?" and a policy problem: water pollution in Florida. The conclusion of this essay presents a response to this problem: a performance art piece designed to teach manatees about mortality.
\end{abstract}

\section{Introduction}

The performance of identity involves impression management, social skills, and selfreflexivity. To perform identity in media environments involves writing our identities into being. Media environments have facilitated a new kind of selfhood - brand - in which we model our identities on celebrities. However, because brand identity has no ethical grounding, it raises legitimate concerns. To incorporate ethics, I perform my 
identity through mystory, Gregory Ulmer's genre of reflexive writing. By composing a mystory, I consult with an avatar - which in Hindu tradition was a god descended into earthly form - that reveals my ethical condition and a pathway through it. This consultation functions as pharmakon (Derrida, 1995), revealing truths to me which both wound and heal.

In mystory, the avatar is immanence rather than a supernatural being. The avatar intimates an emblem of identity drawn from my journey. This emblem functions as an "image of wide scope," a concept of Howard Gruber's which "serves as a kind of conceptual and aesthetic focus for a person's developing inquiries" (Perkins, 1981: 242). Darwin's tree of nature is one such image. "This idea and sketches of it occurred early in Darwin's quest for a theory of evolution and survived to become the only figure in Darwin's Origin, thus informing the investigation throughout" (Perkins, 1981: 242). Like Darwin, I seek an emblem/image of wide scope that will guide me in my quest for knowledge.

Ulmer's mystory differs from conventional consulting, in which an expert (subject) pronounces a verdict on a problem (object). Rather, in mystory, there are no clear lines between expert and problem, subject and object, self and other. Ulmer writes, "To function as a consultant, you accept an event of catastrophe as disclosure, as oracle or parable addressed to me, showing me the limits of my being, as my own threshold or bifurcation point" (Ulmer, 2012: 79). Catastrophe disrupts all boundaries; it presents at once the dimensions of the problem, my role in it, and a pathway out of it. Oedipus' effort to free Thebes of plague points to the source of the problem in himself.

Water pollution in Florida is catastrophic, and I have a role in it. By learning about water pollution, I address a more personal question, "What does it mean to be a man and to be human?" More specifically, "How do I lead an ethical life?" To address these questions, I encounter specific areas of my identity: family member, westerner, consumer, and scholar. The mystory traces a route through these domains, which Ulmer refers to as the "popcycle, $[\ldots]$ an ensemble of discourses into which members of a society are "interpellated"' (Ulmer, 2003: 24-5).

This tracing of the popcycle is aesthetic; it follows the route of the signifier, gathering 'scenes of instruction' from the four popcycle quadrants - family, community, entertainment, and discipline - using puns, homonyms, figures, atmosphere (mood), and analogy. A scene of instruction is the moment one learns the shared consensus about identity, such as the differences between male and female. Each scene of instruction has two components. First there is a structural component; I learn a lesson about the culturally enforced boundaries of identity categories. Second, there is a dramatic component: a particular person - me - experiencing the lesson. The impact of each lesson can vary depending upon my age, my role in the scene, and the details of the scene.

Scenes of instruction structure our entry into ideology and into language. Roland Barthes, in A Lover's Discourse, refers to the catalogue of scenes, which includes both models of exemplary behaviour and forbidden behaviour, as an "image-repertoire." We compose mystories in the middle voice, Barthes' term for the style of self-conscious 
modernist writing that explores one's existence in language, in order to receive our own image-repertoires. In my mystory, I also employ the 'middle look,' a photographic analogue of the middle voice; I photograph a re-created scene of instruction, then select and arrange a series of anecdotes of additional scenes, including scenes from my life as well as scenes from the public catastrophe that invoke memories of this initial scene. From these scenes, I compose an emblem that reflects the catastrophe in me. We not need to accept the ideological baggage of the image repertoire since we seek to use it for other purposes. I use my emblem as a means of attunement to address the policy problem of water pollution in Florida. The conclusion of this essay presents the response to this problem: a performance art piece designed to teach manatees about mortality.

\section{Ereignis}

Mystory is a means to undergo Ereignis, Heidegger's term for the appropriation of one's agency. James Magrini (2009) defines Ereignis as "the lighting and clearing event of truth's happening (aletheia), the temporal event of appropriation of the historical destining of Being." Heidegger framed Ereignis in relation to Nietzsche's comment, "Let us imprint the emblem of eternity on our life!" (Ulmer, 2012: 93). What does this Ereignis mean in practice? Though I theorize identity in the pages below, my real purpose here is to undergo it, to assume my agency by recognizing the emblem of eternity stamped upon me.

Electracy, Ulmer's term for the information apparatus that follows orality and literacy, puts Ereignis within reach of ordinary people. Ulmer notes, "Nietzsche could have Moment 'in his body,' without imaging. Ordinary people, however, need the help of a prosthesis and practice to bring these capacities into everyday use." What prostheses and what practices will bring about these capacities? The means are poetic: "Ereignis [...] is not available to the representative-calculative thinking and to individual experiences of men. It is, rather, given to the essential thinker, the poetic dweller, the seer and the shepherd, in his realization of his belonging-together with Being" (George, 1998: 254). The Internet brings the means of poetic research within our grasp by enabling us to sample and mix texts and discourses the way experimental artists and poets do.

The moment of Ereignis draws together past, present and future, enabling us to make wise decisions. Heidegger (2004:109-110) calls this moment "originary time"; "Within this prevailing forward of that which has been into the future, which, directed backwards, opens up that which earlier already readied itself as such, there prevails the approach of a coming and a still-presencing (future and having-been [past]) in one: originary time." Originary time creates a rift in unfolding time. A famous example of this rift occurs in Proust's Remembrance of Things Past when he tastes the madeleine. The great work of art is both a product of this originary time and a means for other people to access it. 
Paradoxically, I recognize the stamp of eternity upon me when I recognize my finitude. Magrini (2009) writes, “ [...] it is the withdrawal or recession of Being in finitude that draws open the Ereignis, and this notion has been linked to the concept of Earth, as radical finitude." The work of art, which emerges from the Ereignis, initiates a new time by establishing a beginning that must be communal. "While one's death cannot be shared, Heidegger certainly appears to suggest that it is the collective anticipation of death that opens the possibility of a people 'temporalizing' (in an authentic moment of ecstatic temporality) as a historical culture."

The artist experiencing Ereignis does not possess but is possessed by Being. "Heidegger is concerned with our responsiveness and receptivity to Being, the openness that allows for an authentic stance within the enigma of unconcealedness" (Magrini, 2009). By following the signifiers of the catastrophe and my poetic tracing of it through the popcycle, I open myself to Being. This opening is Ereignis.

\title{
3. Mystory: the Garage D'Or of Ereignis
}

As a human/man/citizen/scholar/artist I have a responsibility to myself, to my family, and to my environment. What are the reaches of my power? How do I exercise it appropriately?

In Orlando, Florida, where I live, water quality is now of critical concern, much as it is in most of the rest of the world. What is my relationship to this crisis? In my quest, I find this story in the local paper (Spear, 2013):

\begin{abstract}
Water is on Florida's Mind this Earth Day
Monday is Earth Day - and three years to the day since the flame-engulfed Deepwater Horizon oil-drilling rig sank in the Gulf of Mexico [...] But as scientists continue to examine the Gulf for damage from the 2010 oil spill, Florida has refocused its concern on other waters in trouble, including Central Florida's ailing Indian River Lagoon, the Panhandle's shriveling Apalachicola River, South Florida's polluted Lake Okeechobee and algae-infested springs across the state's northern half. [...]

"In Florida we have a very water-dependent, sensitive environment where small changes in water quality can make huge changes in biological integrity," said [John] Hankinson [a former U.S. Environmental Protection Agency regional administrator], who thinks the state's ongoing water challenges are more pressing than residual harm from the 3-yearold oil spill. "The Indian River Lagoon is a great example," he said. "We've spent millions of dollars in the lagoon to deal with nutrient pollution, resulting in great improvement in the health of the seagrasses and fisheries. Then bam! Out of nowhere comes this algae 'superbloom,' which has decimated the seagrass beds. "It's left everybody thinking, 'Wow, we worked so hard on this, and this is the result we get?',
\end{abstract}

This feeling expressed by Hankinson - the "Bam!" that comes out of nowhere - is the feeling of Ereignis I want to enown. I trace it in the text that follows.

A scene of instruction about being human. It is 1973 and I am eight years old, in the car with my mother and younger siblings in the family car. As we pull into the 
driveway, we hear a news story on the radio about people dying in an accident. I opine that people die because they make stupid mistakes and that if I don't make stupid mistakes, I won't die. My mother starts laughing: "Everybody dies," she says, "even you!" "BAM!" I feel as if I had been hit below the belt. I think, "I am learning my fate too late," but had I learnt it earlier, would I have been better off? I see my future, dying alone. No one can die for me. A minute ago I was ignorant. I have crossed a threshold. What will remove this burden? Religion? It is just a lie and a cop-out for the weak. I experience dread for the first time. How to imagine not being? Only by being both a subject and a non-subject. Impossible.

What stands out about this scene now is the garage door, an utterly mundane garage door, as seen through the car's windshield. Since nearly any garage door will serve as an analogue, here is a photo I took of my current garage door.

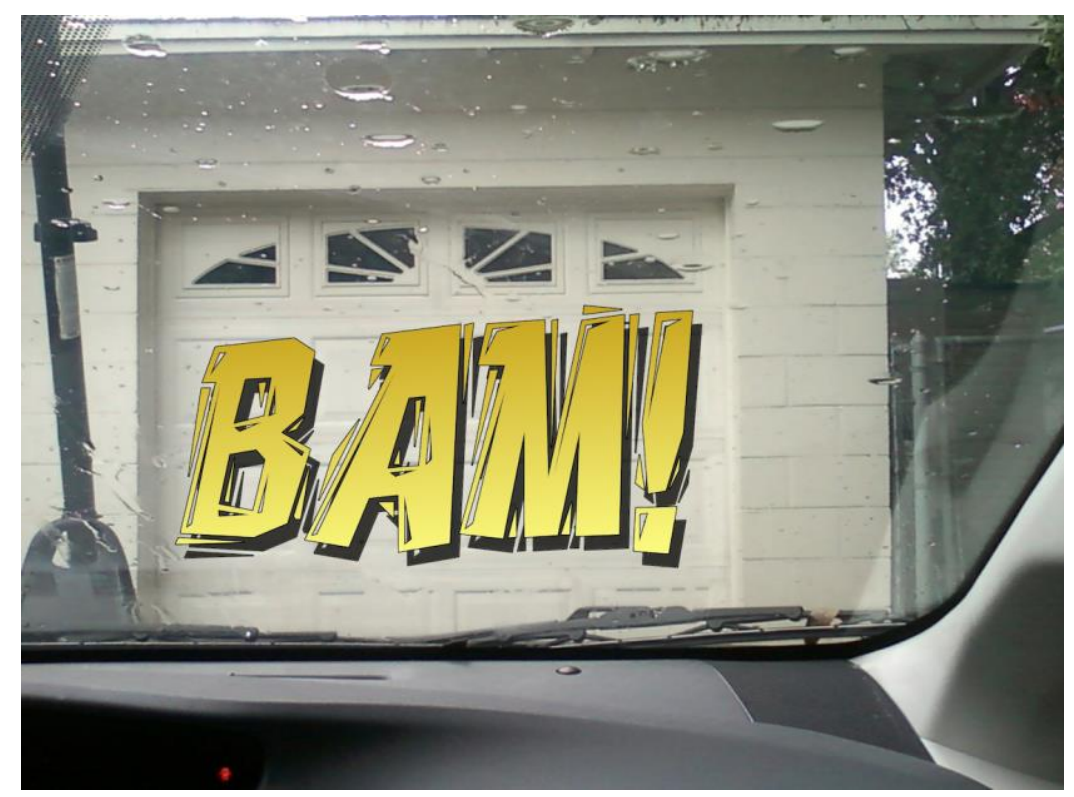

(2013) The Garage D'Or of Ereignis. Photo: Barry Mauer

The garage d'or is my gateway to the infinite in the moment. It "imprints the emblem of eternity on [my] life." D'or means golden in French. Why D'or instead of Door? I remember one of the films I saw in college - Luis Buñuel's L'Age D'or - that convinced me to declare a major in film and cultural studies. Also, I remember a record store in Minneapolis called Garage D'Or. Garage D'or was part of a lively music scene in Minneapolis full of garage bands. When I got off the bus from work, I spent my pay there. Once in Florida, I missed the noise coming from those garage bands, but I could still buy the records.

A garage is where we put junk we are not sure we want in the house but are not sure we want to throw away. The garage is also a place of reinvention and renewal. Garage D'or, the record store, turned the trash rock of garage bands into cultural gold. One of the garage bands I saw in Minneapolis in the 1980s was The Mekons. They recorded a 
song called "Garage D'Or," from their 1986 album The Edge of the World. The lyrics include the following:

Oh well, anyway I never sang no beginning because you never want-ow! - find no beginning. It's already gone and past. Whatever you're after, you'll never find the beginning of it. And that's why you'll always be too late. The only thing you'll ever find is the end of things. Whatever happens, it'll be what you didn't want to happen. Whatever doesn't happen will be the thing you want.

The "bam!" is a "wow!" but also an "ow!"

\section{Gold}

While following my connection to gold in the section that follows, I explore further my relationship to mortality, to being human, to power and to catastrophe.

A gold record is the sign a band has sold half a million units. In pursuit of gold, musicians used a lot of vinyl, a petroleum product. Both oil and gold pollute. Gold extraction demands a huge amount of energy - usually in the form of oil - and the use of cyanide and mercury. These pollutants often leak into the water, killing fish and entering the food supply: "Consider a ring. For that one ounce of gold, miners dig up and haul away 30 tons of rock and sprinkle it with diluted cyanide, which separates the gold from the rock. Before they are through, miners at some of the largest mines move a half million tons of earth a day, pile it in mounds that can rival the Great Pyramids, and drizzle the ore with the poisonous solution for years" (Perlez and Johnson, 2005).

If you want to make gold, you heat iron to billions of degrees in the centre of a giant star during a supernova - a very big BAM!

The path that leads from the multitude of anonymous and abstract particles engendered by the Big Bang to the infinite variety of forms and states, to the moving intimacy of the things we know and love, this path has to go through the star, whilst the star must come from the cloud, the cloud from light, and light from the primordial void. [...] Such was once the good fortune of the atom. There were secret bonds and nuclear wedlock, and behold! (Cassé, 2003: 195-6)

The etymology of gold is aurum in Latin, meaning, "glow of sunrise"; the aur-prefix in aurum provides another link between gold, the sun, and my love of music, which is represented in the word aural. Sometime in the future, our own sun will expand until its circumference is greater than that of the Earth's orbit. Then "One day, the Sun will die, huge and red, victim of its own excesses, and all the atoms of the dead, and of the stones and flowers, will return to it. The atoms of Earth will be restored to the sky" (Cassé: 194). The Earth's gold, which formed in a sun, will return to a sun and then emerge again. "In his Theogony, Hesiod tells us how Gaea, the wide-bosomed Earth, 
arose from the vast and dark Chaos, accompanied by Eros" (Cassé: xi). Emerging from chaos, we live in Eros, then return to chaos.

Gold extraction produces negative externalities, which are costs that are not included in market prices but are passed on to others who do not directly benefit. Those who produce gold leave us their shit. Following the market collapse of 2008-9, Douglas Henderson produced a work of art titled Dukatenscheißer [gold shitter]. "This Dukatenscheißer is an articulated tower of sewer pipes, coated in gold leaf, and punctuated with trumpet-like speakers. From these, apparently emanating from the hollow interior, pours a symphony of orchestrated noises, all connected to money and liquidity" (Milne, 2009: 1).

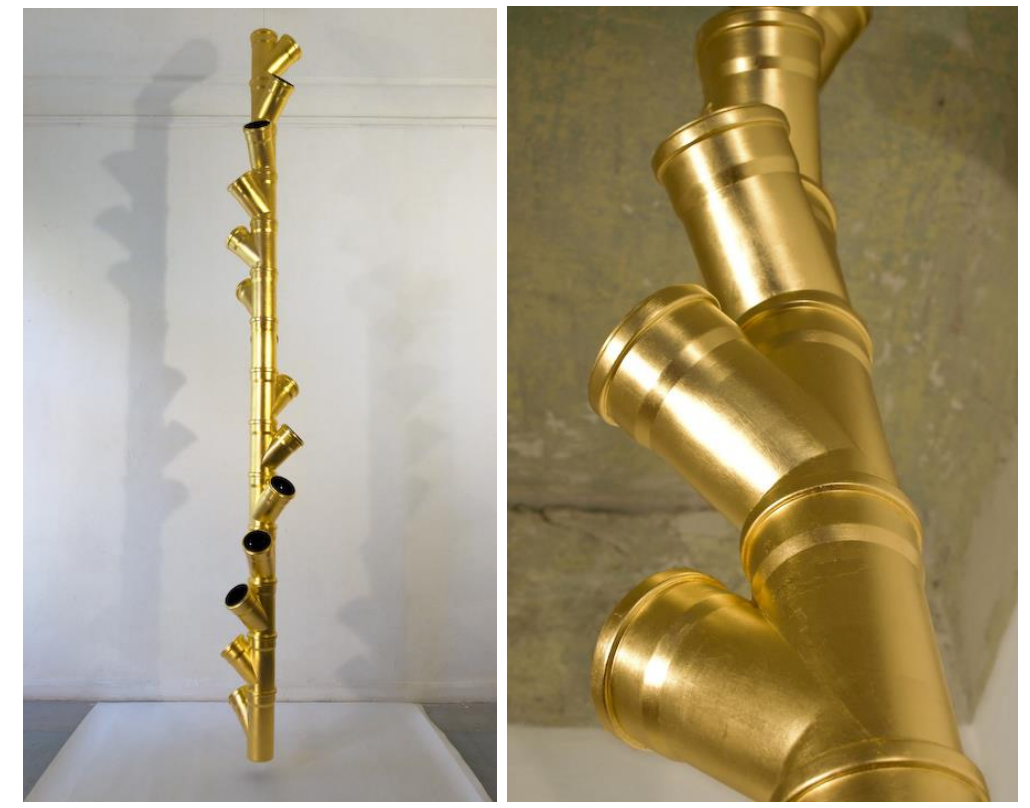

Dukatenscheißer (2009) Plastic sewer pipes, 22 Karat gold, loudspeakers, 12 channel audio. $36 \mathrm{~cm}$ x 36cm x 350cm, 35 min. loop. Photo: Douglas Henderson, Copyright 2009

Gold relates to power in multiple ways. It is born of a supernova. It conducts power (electricity) better than any other metal. It is a sign of economic power. In Henderson's work, it is also recorded sound (the aurum/aural connection). Freud traced a link between gold and excrement that puts gold's power "below the belt." "Freud was not the first to recognise the strong association between excrement and treasure in the western imagination, but he was the first to understand how this pairing is knitted into certain typical expressions of adult sexuality. He found that gold and shit are connected in folk-jokes couched as dream-anecdotes" (1). Henderson connects these elements in his golden sewer pipe.

Freud equated the fetishising of gold with a childhood anal fixation: the desire to withhold shit. This fetish is connected to anxiety, a wish to hold onto power, and a refusal to bestow it as a gift. "This uneasiness seems to have its roots in the capacity of money to split any exchange into mutually indifferent acts, separated in time, and so enabling its consummation to be deferred indefinitely" (2). Money comes to represent 
the potential to store power and to delay its use, but this power to delay creates neuroses; “ [...] as money lost weight and sensory presence - metamorphosing from treasure to coins, paper to plastic, to binary data - so the status of the desires wrapped up in delayed consummation became, as it were, constipated: bottled up and knotted into ever more bizarre forms" (2).

Henderson, according to critic Louise S. Milne, uses his art to undergo the experience of the Dukatenscheißer. "The artist is the occult vessel in whose bowels (so to speak), these ingredients have been 'cooked.' The technology of recording sound is itself a kind of alchemy" (3). The Dukatenscheißer is a hybrid, like the images in dreams, that combines multiple images from different discourses/domains into a condensed image. "Any hybrid image is an adynaton, made of parts of mundane things; it is the fact that these parts are fused together (as in a winged-human) which indicates the entity's occult status. Adynata can also be regarded as end-products of the Freudian dream-processes, condensation and displacement" (3).

This Dukatenscheißer is fundamentally deconstipated; it turns inside out the tradition on which it is founded. Its mobile choreography "solves" the splitting and thwarting of desire at the root of money-neurosis, and recovers the multiple sense of "release" in the earlier peasant jokes. Henderson comments, "Though the coins flow downward, it is in no way a depressing piece. I see the financial crisis also as an internal crisis within myself, ('...purgatory can here be understood as a place or state within the self...').” (4)

Henderson's work creates an athanor: "an alchemical womb-crucible - distilling out an occult quintessence from mundane ingredients [...] the Dukatenscheißer re-imagines the lower half of the body (the zone-below-the-belt) as a joyous absurd athanor" (6). My mystory will produce an athanor.

The themes of gold, excrement, and power lead me to another association: the dorbeetle. This creature may also help me learn to be a man/human.

dor•beetle a common European dung beetle, Geotrupes stercorarius.

("Dorbeetle," 1991)

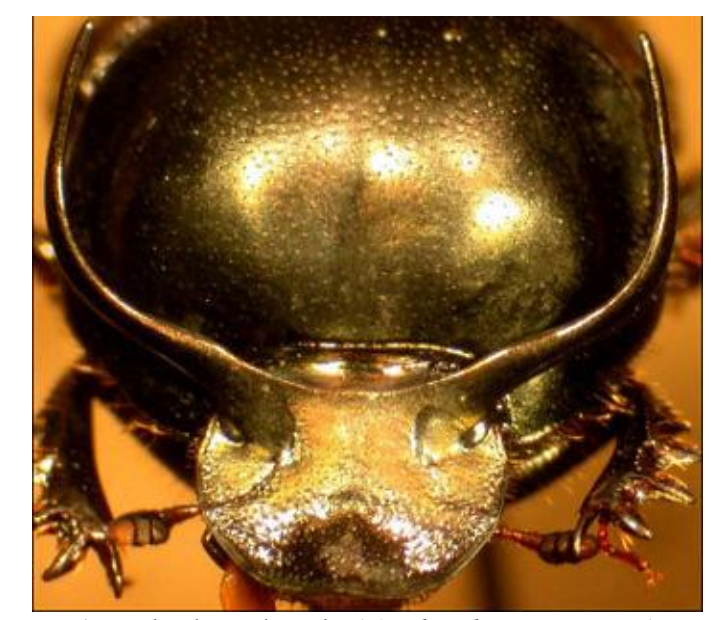

A male dung beetle (Onthophagus taurus)

Photo: Armin Moczek/National Science Foundation 


\section{Bigger bodies or more sperm: a dung beetle conundrum}

If Franz Kafka were writing today, he might have chosen an insect other than the dung beetle to represent The Metamorphosis's despairing protagonist, Gregor Samsa. Dung beetles, it turns out, merit the title "World's Strongest Insect," according to a recent study in Proceedings of the Royal Society, researchers have found that certain males of the dung beetle species Onthophagus taurus can pull 1,141 times their own body weight - that's like a 154-pound human lifting six double-decker buses, according to the AFP.

The strength has to do with sex (are we surprised?). Some males will fight each other for the right to mate with a female, locking horns and pushing, writes the Telegraph. Smaller and weaker males, on the other hand, forgo pugilism, relying on other, ahem, assets - specifically, "substantially bigger testicles," according to the Telegraph. "Instead of growing super strength to fight for a female, they grow lots more sperm to increase their chances of fertilizing her eggs and fathering the next generation," said researcher Rob Knell, in the AFP article. This suggests that when their beefy rivals aren't looking, the underlings swoop in to romance the beetle babe on the sly, "[using] their higher sperm count to up their chances at impregnating her in their single shot," writes Scientific American (Leibach, 2010).

The male dorbeetle faces a choice: brawn or sperm (power above or below the belt). Humans, with our ability to capture energy, have more power than the dorbeetle, yet our powers (intellectual, economic, military) are just as tied to hormones. Can we face our own conundrum - rapid economic growth or the rapid destruction of the Earth's biosphere - before the catastrophe? Are we driven by biological urges to rush ahead? Is it already too late?

\section{Bam!}

In the following section, I note the shock of catastrophe and its connection to the lure of comfort and addiction. As I awoke this morning, I remembered that the ancient city of Bam, Iran, was destroyed in an earthquake a few years ago. I find the following information:

\section{Ancient Bam}

Located in southeastern Iran, 200 kilometers south of Kerman, the ancient city of Arg-eBam is made entirely of mud bricks, clay, straw and the trunks of palm trees. Bam prospered $[\ldots .$.$] as a commercial and trading center on the famous Silk Road. ("Bam$ Citadel")

\section{Modern Bam}

The earthquake, occurring at the early hours of the morning in winter when most people were in bed, resulted in the highest casualty rate and the most profound social impact in the recorded post-1900 history of devastating urban earthquakes in Iran. (Berberian, 2009) 
While reading about the Bam earthquake, I learn a new word: "Manishock: The largest shock in an earthquake sequence." Becoming a [hu]man involves a shock similar to the manishock. In the face of shock, we are powerless and we become vulnerable to one of the greatest problems threatening humans and the planet on which we live: addiction.

\section{Iran Opium Addicts Find Supplies Despite Earthquake}

BAM, Iran (Reuters) - A city in the corridor of illegal drug trafficking between Afghanistan and Europe, Bam is home for many of an estimated two million drug addicts in Iran, according to government officials. Despite the quake devastation, several people said there was no trouble finding cheap supplies [...] the ancient Silk Road city was still awash with opium even though almost every other service was severed by the December 26 quake that killed at least 30,000. (Oliver, 2004)

\section{Opiates of the Iranian People: Despair Drives World's Highest Addiction Rate}

TEHRAN - If he could afford it, Ali Nariman would drink beer, he says. But like most Iranians, he is poor, and so takes his solace in the form of a small gray ball of opium. Swallowed whole for maximum absorption, the ball takes only half an hour to deliver the warm, surging relief that inhabitants of the Persian plateau have long associated with advanced age. When an earthquake leveled the city of Bam in 2003, among the emergency supplies rushed to the scene were doses of methadone, a synthetic drug used to treat heroin and morphine addicts, for the 20 percent or more of the population believed to be addicted. So many Iranians rely on opiates that an influential government analyst suggests the state itself should consider cultivating poppies. "Yes," said Azarakhsh Mokri, director of the Iranian National Center for Addiction Studies: "A strategic reserve of narcotics." (Vick, 2005)

Addiction gives us a false sense of security by allowing us to escape painful realities. Our drive for comfort and for control deepen our addiction to fossil fuels and to consumption at the expense of anything else; our ever increasing capacity to compete, conquer, and consume makes us more threatening than the mightiest dorbeetle. Paradoxically, our drive for power has led us to powerlessness and unmanageability.

\section{7. (B.A.M.) Being a Man [ATEE]}

In the following section, I find that the problem of water pollution and the problem of owning manhood are connected both metonymically and homologically to the manatee, a creature native to Florida. When Christopher Columbus first saw manatees, he thought they were mermaids. Manatees grow up to 4 meters long and weight up to 590 $\mathrm{kg}$. They are endangered mammals that live in rivers and along the coast. We lose many manatees each year to boating accidents, but this year there is another crisis:

More than 550 manatees have already died in 2013 - that's over 10 percent of the Florida manatee population! The death toll in the first few months of this year has already 
surpassed the total number of manatees that died all of last year. This recent surge in manatee deaths was caused by toxic blooms of algae (the so-called red tide) and a huge dieoff of seagrasses, the manatees' main food source. (Fleming, 2013)

What caused the algae superbloom? It was a lot of small decisions and the role of chance (dasein's thrown-ness) that pushed the environment to a tipping point. The algae thrive on phosphorous, which is in the chemical fertilizer that runs off farms and lawns. It also thrives on warm water, which is more common because of the changes that humans have made to the environment. The algae releases "a nerve poison known as brevetoxin. [...] Manatees, birds, dolphins and other animals can be killed by consuming the poison, either by accidentally eating the algae or by ingesting small organisms clinging to sea grass that have soaked up the poison while filtering seawater" (Wines, 2013). This poison also affects humans: "Residents and tourists regularly have respiratory problems after inhaling brevetoxins while strolling on beaches near red tides. People can also become ill after eating oysters and clams that have absorbed the toxin" (Wines, 2013). Fertilizer from farms runs off into the Caloosahatchee River, which flows into the ocean at Fort Myers. "Manatees are attracted there every year by a warm-water discharge from a local power plant, Dr. DeWit [Dr. Martine DeWit, a veterinarian with the state's Fish and Wildlife Conservation Commission] said. 'We've seen in the past that when algae blooms coincide with manatee movement, it results in catastrophic mortality,' she said." (Wines, 2013)

Are manatees aware of their mortality? Do they know they are at greater risk of dying from an algae bloom in their search for wellbeing? Do they understand the chain of consequences arising from the chemical fertilizers that farmers put on their fields and that homeowners put on their lawns? Do they know that organic fertilizers (including animal shit) work more slowly and that their nutrients are far less concentrated than inorganic fertilizers, thus posing less risk to them (cf. Savonen, 2008)? Humans are capable of learning about the dangers of brevetoxins. Nevertheless, we exhibit a wilful ignorance about our role in creating them. What does it mean to be human? Awareness of mortality. How do we deal with it? One common way is denial.

Some humans face mortality much sooner than others. For them, denial is less of an option. In Chicago, the murder rate for youths has reached record highs. Below is a report from a program in Chicago called Being A Man (B.A.M.), intended to address the problem:

Why have we not made more progress in improving the long-term life chances of disadvantaged youth? One candidate answer is that while the U.S. devotes considerable resources to developing academic skills - total annual spending on K-12 public schooling equals $\$ 550$ billion (U.S. Census Bureau, 2010) - we devote relatively little attention, at least outside the earliest elementary-school grades, to addressing other important determinants of student success such as what Dodge et al. call "social-cognitive skills." Examples include self-control, conflict resolution, future orientation, and social information processing, such as the ability to accurately infer the intentions of others. (“Bam - Sports Edition1”, 2012) 
My "social-cognitive skills" have been lacking at times. When I was twenty years old, I visited my Grandma Lucy in her south Florida condominium with my parents and siblings. Grandma Lucy opened her door, noticed I had a beard, and said, "Oh my God, you're so ugly I'm going to die!" She led me to her room and closed the door. "So, you think a beard makes you a man? Your uncle grew a beard; it made him look like a bum! Promise me you'll shave it."

My grandmother inferred my social-cognitive skills based on my beard and judged that I was uncivilized, wild, resisting domestication. She was right. I had fallen under the influence of the garage d'or, the wild garage band rock scene in Minneapolis. Familial authority figures often told me to 'be a mensch' (Yiddish for 'be a man'). It usually meant, 'Sit up straight!' but also reminded me of the need for decorum in general. Self-control took energy and I did not want to spend my energy on being a mensch.

\section{A reading}

By luck - or was it Fate? - I find a pattern emerging from research in my mystory. The chosen signifiers, such as "d'or," "bam," and "man," lead me to various themes: domestication/wildness, striving/limits, production/waste, power/powerlessness, and the vibrations of earthquakes and of music. I am now ready to compose my emblem. It is the image of the "Bam!" on the Garage D'or of Ereignis accompanied by this motto: "Embrace Mortality Poetically!" "Poetically" can include any style or mood: creatively, playfully, dramatically, musically, etc. This emblem allows me to take in, at once, all of the pathways I have traced in my mystory. It shows me how to navigate my inner and outer being. In the project I outline below, I explain how we can create a philosophical furnace, or athanor, from this emblem to protect the community and the manatees.

\section{Project: Manatee Athanor}

I do not want to tiptoe around mortality; I want to embrace it poetically, transforming my feelings of dread into activism and community building. I learn to embrace the mortality of humanity by addressing the mortality of the manatee.

The Spanish explorers who came to Florida imagined the manatees as adynata: humans with fish parts below the belt. The imaginative alchemy that led to the mythical mermaid figure can now help us solve the problems faced by manatees and humans. But first we need an alchemical furnace:

In alchemy, an athanor is a furnace used to provide a uniform and constant heat for alchemical digestion. The athanor was also called Piger Henricus ("Slow Harry"), because it was chiefly used in slower operations, and because when once filled with coals, it keeps burning a long time. For this reason the Greeks referred to it as "giving no 
trouble", as it did not need to be continually attended. It was also called the Philosophical furnace, Furnace of Arcana, or popularly, the Tower furnace. (“Athanor", 2013)

Manatees require "a uniform and constant heat" to stay warm in the winter months. Without it they die of exposure to the cold. As power plants came online in Northern Florida and discharged their warm water into inlets, the manatees moved up the coast. In central Florida there are a handful of natural springs that provide warm water year round. As recently as 2005, $15 \%$ of all manatees in Florida use the natural springs during the winter, $60 \%$ use the power plant discharges, and the other $15 \%$ use thermal basins in South Florida. "Since 1986, rates of cold-related deaths in southernmost Florida (10.0\%) have exceeded those in areas with natural springs in central and northern Florida (8.8\%)" (Laist and Reynolds, 2005: 739). Evidence suggests manatees used to winter in the warm-water springs but that humans hunted them, driving them south. They are currently on the endangered species list.

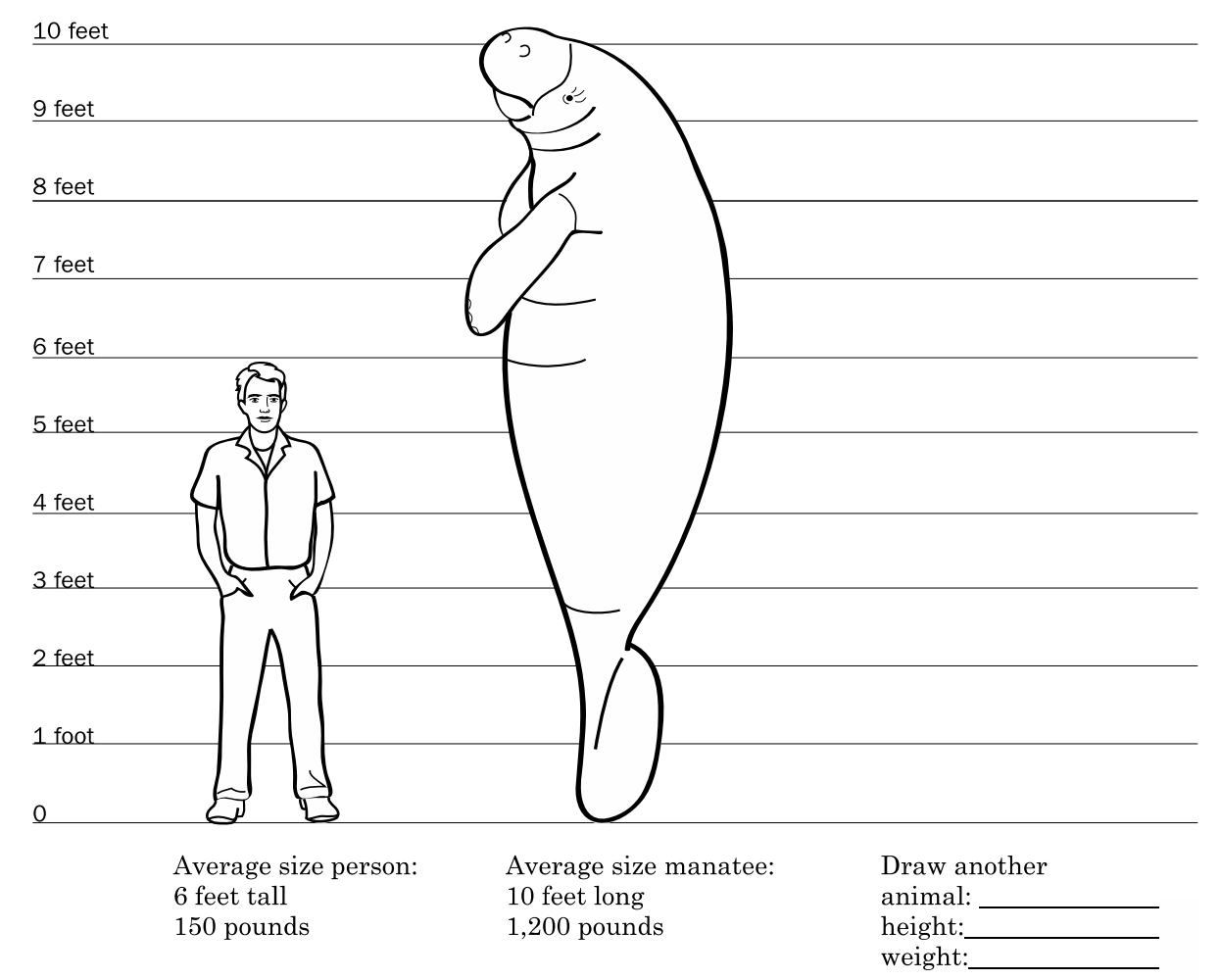

(2008) Manatee Activity Workbook. Florida Fish and Wildlife Conservation Commission: Imperilled Species Management Section. MyFWC.com.

My goal is to learn about mortality. Since the most effective form of self-persuasion is teaching (Aronson, 1999), I propose the creation of a group, open to anyone, named "The Dor-Beatles," that will teach the manatees about mortality through performance 
art. Our group will include children old enough to understand their own mortality. We will use the natural springs in Florida as a rehearsal space that is also athanor, since the springs maintain the water at a constant heat. During rehearsal, we will use philosophical alchemy - the poetic means of the mystory - to transform our personal and collective problems into lessons for the manatees. Our performance for the manatees will emerge from Ereignis, the clearing, which allows us to form a community in our collective anticipation of death. For our actual performance, we will travel to the power plants where manatees gather, dressed in Beatle suits like those worn by John, Paul, George, and Ringo when they performed at Shea Stadium, but ours will be gold lamé. Any additional humans are welcome to attend. The lesson plan includes the following:

1. Teach the manatees that they are endangered and that their numbers are shrinking.

2. Teach them that humans are endangered too, although there are over seven billion of us and our numbers are growing. We are endangering our own existence by our growth, our hubris, and our addictive behaviours.

3. Teach them that Gaea, the world they know, emerged from chaos.

4. Teach them about power, how we attain it, use it and waste it.

5. Teach them about power plants, how they warm the water that keeps them alive in the winter, but also how they promote the algae blooms that produce the brevetoxins that poison their sea grass.

6. Teach them that natural springs provide warm water in the winter too, but these springs must be protected from humans.

7. Teach them about externalities, the costs of human behaviours that are passed on to others. The manatee is currently paying some of the external costs for our power, which results in more algae blooms and more dead manatees.

We will use the following means to instruct the manatees:

1. Poetry

2. Visual Arts

3. Music

4. Lectures

5. Electronic media such as Prezi

6. Dance

7. Drama

The performance project owes its inspiration to artist Joseph Beuys' piece, "How to Explain Pictures to a Dead Hare."

Beuys, whose head was covered with honey and gold leaf, held a dead hare in his arms and carried it, walking through the exhibit and talking to it, from picture to picture, letting it touch the pictures with its paw. After the tour was finished he sat down on a 
chair and began to thoroughly explain the pictures to the hare "because I do not like to explain them to people." (Adriani, Konnertz and Thomas, 1979: 130)

Beuys writes, "Gold and honey indicate a transformation of the head, and therefore, naturally and logically, the brain and our understanding of thought, consciousness and all the other levels necessary to explain pictures to a hare" (cf. Ulmer, 1985: 255). We ought, also, to teach the manatees about gold, to explain to them that gold was transformed in an exploded sun and that in our lust for gold we have poisoned their waters with cyanide and mercury as we strive to extract gold from ore. We will teach manatees that, like gold, we will all return to the sun.
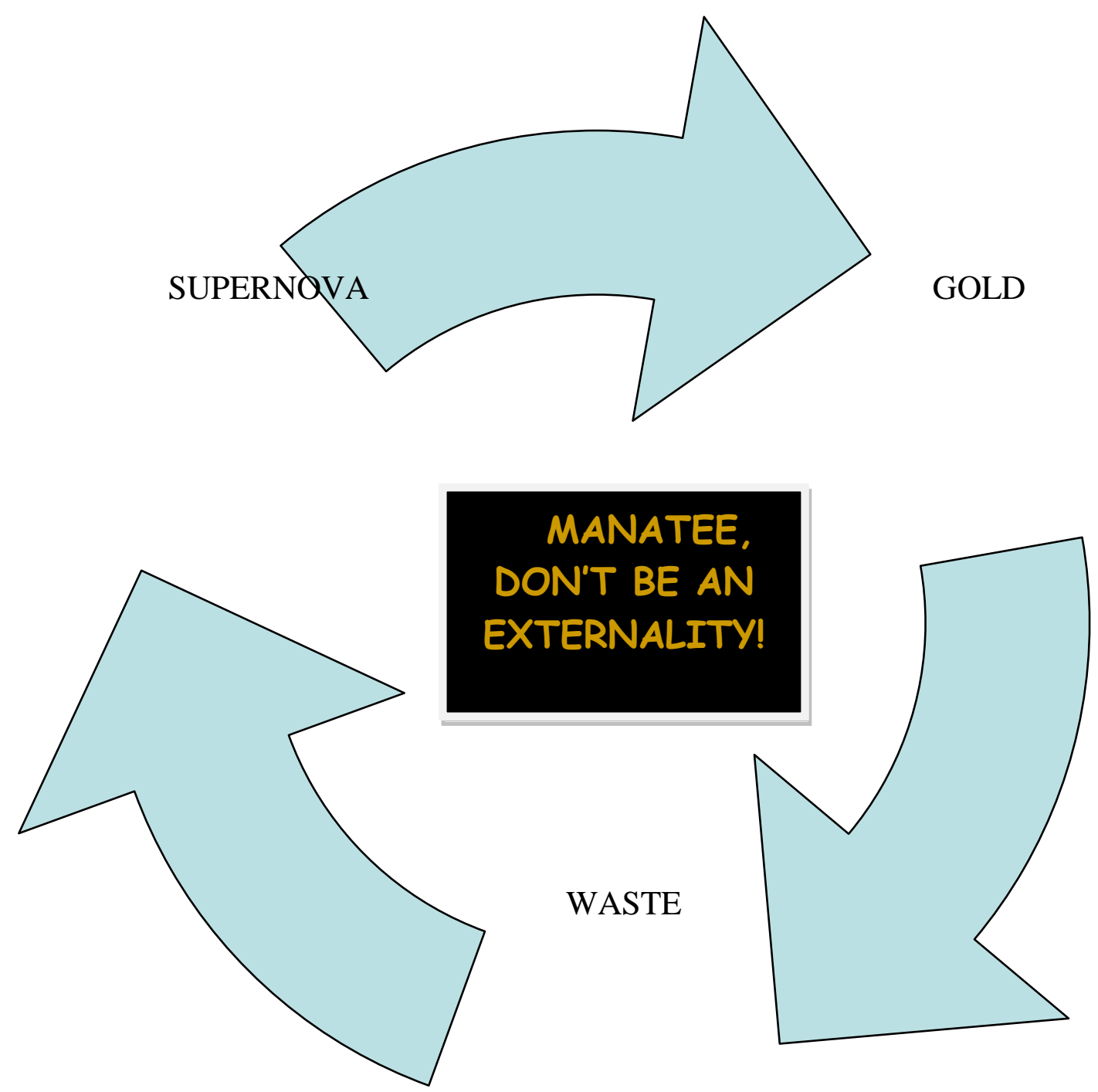


\section{References}

Adriani, Götz, Winfried Konnertz and Karin Thomas (1979): Joseph Beuys: Life and Works, trans. by Patricia Lech. Woodbury, N.Y.: Barron's Educational Series, Inc..

Aronson, Elliot (1999): "The Power of Self Persuasion." American Psychologist, 54: 875-884.

"Athanor." Wikipedia. http://en.wikipedia.org/wiki/Athanor (accessed 28 April 2013).

"Bam: Iran's Ancient City" (2003). http://www.farsinet.com/bam/ (accessed 28 April 2013).

"Bam-Sports Edition1. University of Chicago Crime Lab Research and Policy Brief" (2012). www.joycefdn.org/assets/1/7/BAM-Sports_Edition_Report.pdf (accessed 28 April 2013).

Barthes, Roland (1985): A Lover's Discourse: Fragments, trans. by Richard Howard. New York: Hill and Wang.

- (1977): Barthes by Barthes, trans. by Richard Howard. New York: Farrar, Straus, and Giroux.

Berberian, Manuel (2009): “Bam Earthquake.” Encyclopaedia Iranica. http://www.iranicaonline.org/articles/bam-earthquake-2003 (accessed 28 April 2013).

Cassé, Michel (2003): Stellar Alchemy: The Celestial Origin of Atoms, trans. by Stephen Lyle. Cambridge: Cambridge University Press.

Derrida, Jacques (1995): Archive Fever: A Freudian Impression, trans. by Eric Prenowitz. Chicago: University of Chicago Press.

"Dorbeetle" (2010): Random House Kernerman Webster's College Dictionary. New York: K Dictionaries Ltd. Random House, Inc..

Fleming, Elizabeth (April 24, 2013): "MANATEE CRISIS: record deaths reported." Defenders of Wildlife email.

George, Vensus A. (1998): Authentic Human Destiny: The Paths of Shankara and Heidegger. Washington, D.C.: The Council for Research in Values and Philosophy.

Heidegger, Martin (2004): Hölderlin's Hymns. "Germania" and "The Rhine”, trans. by William McNeill and Julia Ireland. Bloomington: Indiana University Press.

Laist, David W. and John E. Reynolds, III (2005): "Influence of Power Plants and Other WarmWater Refuges on Florida Manatees.” Marine Mammal Science 21(4): 739-764.

Leibach, Julie (2010): "Bigger Body or More Sperm? A Dung Beetle Conundrum.” Blog post, http://magblog.audubon.org/bigger-body-or-more-sperm-dung-beetle-conundrum (accessed 28 April 2013).

Magrini, James (2009): "The Work of Art and Truth of Being as 'Historical': Reading Being and Time, 'The Origin of the Work of Art,' and the 'Turn' (Kehre) in Heidegger's Philosophy of the 1930s." Philosophy Scholarship paper 3. http://dc.cod.edu/philosophypub/3 (accessed 28 April 2013).

Milne, Louise S. (2009): “Songs Upon the Air-Loom: Douglas Henderson's Dukatenscheißer and Other Works."

http://www.galeriemazzoli.com/english/Douglas\%20Press\%20release\%20(1).pdf (accessed 28 April 2013).

Oliver, Christian (2004): "Iran Opium Addicts Find Supplies Despite Earthquake.” Reuters. http://opioids.com/opium/iran.html (accessed 28 April 2013).

Perkins, D. N. (1981): The Mind's Best Work. Cambridge: Harvard University Press.

Perlez, Jane and Kirk Johnson (2005): "Behind Gold's Glitter: Torn Lands and Pointed Questions." The New York Times.

http://www.latrobefinancialmanagement.com/Research/Commodities/Behind\%20Gold's\%2 
0Glitter\%20NYTimes\%20Piece.pdf (accessed 28 April 2013).

Savonen, Carol (April 30, 2008): "Here's the scoop on chemical and organic fertilizers." extension.oregonstate.edu/gardening/node/955 (accessed 28 April 2013).

Scholes, Robert, Nancy R. Comley and Gregory L. Ulmer, eds. (2002): Text Book: Writing Through Literature. Boston: Bedford/St. Martin's.

Spear, Kevin (2013): "Water is on Florida's mind this Earth Day." Orlando Sentinel. http://articles.orlandosentinel.com/2013-04-21/news/os-earth-day-disasters-compared20130421_1_bp-spill-deepwater-horizon-oil-spill (accessed 28 April 2013).

Ulmer, Gregory L. (1994): Heuretics: The Logic of Invention. Baltimore, MD: Johns Hopkins University Press.

- (2003): Internet Invention: From Literacy to Electracy. New York: Longman UP. (2012): Avatar Emergency Anderson, South Carolina: Parlor Press LLC.

Ulmer, Gregory with Barbara Jo Revelle, William Tilson and John Craig Freeman (2012): "Miami Virtue and the Ulmer Tapes." Small Cities 3(2). http://smallcities.tru.ca (accessed 28 April 2013).

Vick, Karl (2005): “Opiates of the Iranian People” The Washington Post. http://www.washingtonpost.com/wpdyn/content/article/2005/09/22/AR2005092202287.ht $\mathrm{ml}$ (accessed 28 April 2013).

Wines, Michael (2013): "Florida Algae Bloom Leads to Record Manatee Deaths" New York Times.

http://www.nytimes.com/2013/04/07/science/earth/algae-bloom-in-florida-kills-recordnumber-of-manatees.html (accessed 28 April 2013). 